\title{
Revisitation of the $\mathrm{PCl}_{5}$-Chlorination Reaction of $\alpha$-Amino Acids: Spectroscopic and DFT Insights, and Synthesis of the $L$-Proline-Derived 2,5-Diketopiperazine
}

Marco Bortoluzzi, ${ }^{[a]}$ Fabio Marchetti, ${ }^{*},[b]$ Maria Grazia Murrali, ${ }^{[b]}$ Guido Pampaloni ${ }^{[b]}$

[a] Dipartimento di Scienze Molecolari e Nanosistemi, University of Venezia Ca' Foscari, Dorsoduro 2137, I-30123 Venezia.

[b] Dipartimento di Chimica e Chimica Industriale, University of Pisa, Via Risorgimento 35, I-56126 Pisa.

*E-mail: fabmar@dcci.unipi.it. Tel: +39 0502219 245. Webpage: http://www.dcci.unipi.it/ fabmar/ 


\section{Abstract}

The traditional chlorination reaction of $\alpha$-aminoacids with $\mathrm{PCl}_{5}$ was elucidated by means of

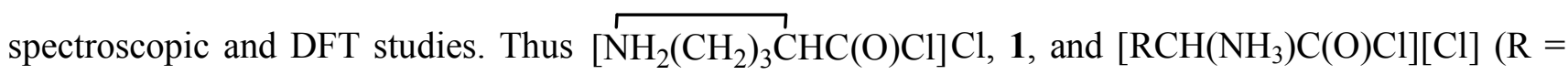
$\mathrm{H}, \mathbf{3} ; \mathrm{R}=\mathrm{CH}_{3}, \mathbf{4} ; \mathrm{R}=\mathrm{CH}_{2} \mathrm{Ph}, \mathbf{5} ; \mathrm{R}=\mathrm{CH}_{2} \mathrm{CHMe}_{2}$, 6) were obtained in high yields from equimolar amounts of $\mathrm{PCl}_{5}$ and $L$-proline, glycine, $L$-alanine, $L$-phenylalanine and $L$-leucine, respectively. Compounds 3-6 resulted to be stable at room temperature under nitrogen atmosphere, whereas 1 rapidly degraded under the same conditions, both in the solid state and in solution. The 1:2 molar reaction of $\mathrm{PCl}_{5}$ with $L$-proline selectively afforded the salt $\left[\mathrm{NH}_{2}\left(\mathrm{CH}_{2}\right)_{3} \mathrm{CHC}(\mathrm{O}) \mathrm{Cl}\right]\left[\mathrm{PCl}_{6}\right], 2$, showing better inertness than the homologous $\mathbf{1}$. The slow degradation reaction of $\mathbf{2}$ may represent a strategy for the clean synthesis of the $L$-proline-derived 2,5-diketopiperazine, which was recovered in $c a$. $60 \%$ yield from a dichloromethane solution stirred at room temperature for several days and purged with nitrogen gas in order to remove the released $\mathrm{HCl}$. Compounds 1-6 were characterized by elemental analysis and IR spectroscopy, and by NMR spectroscopy in the cases of soluble $\mathbf{1}$ and $\mathbf{2}$. Furthermore, the structures of 1-6 were computationally optimized by means of DFT functionals. According to the spectroscopic and DFT outcomes, 1-6 exist in solution as tight ion pairs featured by $\mathrm{NH}---\mathrm{Cl}$ cation-anion interactions, leading to possible $\mathrm{HCl}$ formation and consequent condensation reactions. The less stability observed for 1-2 respect to 3-6 should be associated with the relatively high $\Delta \mathrm{G}$ value of the condensation step.

Keywords: Phosphorus pentachloride; $\alpha$-Amino acids; 2,5-Diketopiperazine; Chlorination Reaction; $\alpha$ Ammonium-Acylchloride 


\section{Introduction}

The activation of the carboxylic acid function by a chlorinating agent may be a crucial, preliminary step for the subsequent functionalization of $\alpha$-amino acids. ${ }^{1}$ The resulting acylchloride species are reactive intermediates which are frequently used for in situ derivatization, however their solid state isolation has been accomplished by using $\mathrm{PCl}_{5}$ as typical $\mathrm{Cl}$ transfer agent (Fischer procedure). ${ }^{1 \mathrm{a}, 2}$ The resulting products have been generally described as "hydrochloride salts", notwithstanding the characterization has relied on limited analytical data ${ }^{1 \mathrm{a}, 2}$ and spectroscopic information are still missing in the literature. In addition, some ambiguity exists about the stoichiometry to be employed in the reaction $\alpha$-amino acid/ $\mathrm{PCl}_{5}$, especially for what regards $L$-proline: for instance, Morán and co-workers used approximate 1:1 molar ratio in chloroform, ${ }^{1 \mathrm{a}}$ instead Liwschitz et al. used a two-fold excess of $\mathrm{PCl}_{5}$ in acetyl chloride. ${ }^{2 \mathrm{~b}}$ The derivative obtained from $\mathrm{PCl}_{5} / L$-proline, independently on the preparation method, was described as a particularly unstable compound, for which storage at temperatures below $-10{ }^{\circ} \mathrm{C}$ was recommended. ${ }^{1 \mathrm{a}}$

In the framework of our research on the reactivity of high-valent metal chlorides, ${ }^{3}$ we came interested in the interaction of $\mathrm{PCl}_{5}$ with naturally occurring $\alpha$-amino acids. Here we revisit such piece of chemistry, showing the first IR and NMR characterization of the products obtained by 1:1 and 1:2 combination of $L$-proline with $\mathrm{PCl}_{5}$, respectively, and thus giving insight into their identity. The study has been extended to glycine, $L$-alanine, $L$-phenylalanine and $L$-leucine (Scheme 1 ), whose acylchloride derivatives are non soluble compounds which have been characterized by elemental analysis and IR spectroscopy. DFT calculations have been carried out in order to optimize the structures of the products and to understand their different stabilities at room temperature.

Furthermore, we show a new, simple route to obtain the $L$-proline derived 2,5-diketopiperazine (dkp, Scheme 1). Indeed dkp belongs to the extensive family of homologous compounds, that possess valuable 
biologic properties ${ }^{4}$ and are considered as promising scaffolds for drug discovery. ${ }^{5}$ Although the 2,5diketopiperazine skeleton is easily available in nature, being found either alone or embedded in more complex architectures, ${ }^{5 a}$ there is currently high interest in developing new synthetic strategies to access 2,5-diketopiperazines. ${ }^{5 \mathrm{a}, 6}$<smiles>[R][C@H](N)C(=O)O</smiles>

$\mathrm{R}=\mathrm{H}$, glycine; $\mathrm{CH}_{3}, L$-alanine; $\mathrm{CH}_{2} \mathrm{Ph}, L$-phenylalanaine; $\mathrm{CH}_{2} \mathrm{CHMe}_{2}, L$-leucine<smiles>O=C(O)[C@H]1CCCN1</smiles>

$L$-proline<smiles>O=C1[C@@H]2CCCN2C(=O)[C@@H]2CCCN12</smiles>

$\mathrm{dkp}$

Scheme 1. Amino acids and the cyclic dipeptide of $L$-proline (dkp).

\section{Results and discussion}

The 1:1 and 1:2 molar reactions of $L$-proline with $\mathrm{PCl}_{5}$ were conducted under nitrogen atmosphere in $\mathrm{CH}_{2} \mathrm{Cl}_{2}$ at $0{ }^{\circ} \mathrm{C}$, and afforded colourless solutions in $\mathrm{ca}$. 1 hour. Thus air sensitive, colourless solids were isolated upon removal of the volatile materials. The solids were maintained at low temperature $(0-5$ ${ }^{\circ} \mathrm{C}$ ) and quickly analyzed by IR spectroscopy. The IR spectra showed a strong absorption due to the carbonyl moiety, occurring at slightly higher wavenumber in $\mathbf{1}$ respect to $\mathbf{2}\left(\mathbf{1}: 1790 \mathrm{~cm}^{-1} ; \mathbf{2}: 1778 \mathrm{~cm}^{-1}\right)$. This absorption decreased in intensity with time, on keeping the samples at room temperature under nitrogen; it completely disappeared after 1 hour in the case of $\mathbf{1}$, and after 24 hours in the case of $\mathbf{2}$. The different inertness exhibited by $\mathbf{1}$ and $\mathbf{2}$, respectively, reflects the different nature of the anion in the two salts. This observation is clearly supported by the outcomes of the elemental analyses $(\mathrm{C}, \mathrm{H}, \mathrm{N}, \mathrm{Cl}$; 
see Experimental) and NMR experiments. Indeed we reproduced the 1:1 and 1:2 molar reactions of $L$ proline with $\mathrm{PCl}_{5}$ in $\mathrm{CD}_{2} \mathrm{Cl}_{2}$. The resulting solutions were analyzed by $\mathrm{NMR}\left({ }^{1} \mathrm{H},{ }^{13} \mathrm{C},{ }^{31} \mathrm{P}\right)$ spectroscopy. Phosphorous oxychloride, $\mathrm{POCl}_{3},\left({ }^{31} \mathrm{P} \mathrm{NMR}\right.$ resonance at $4.6 \mathrm{ppm}{ }^{7}$ in $\left.\mathrm{CD}_{2} \mathrm{Cl}_{2}\right)$ was the only phosphorous-species resulting from the 1:1 reaction (Eqn. 1): in agreement with elemental analysis, this fact indicates that $\mathrm{Cl}^{-}$acts as counterion in $\mathbf{1}$, presumably due to the estimated low $\mathrm{Cl}-\mathrm{POCl}_{3}$ bond energy. ${ }^{8}$ Otherwise, both $\mathrm{POCl}_{3}$ and $\left[\mathrm{PCl}_{6}\right]^{-}$(resonance at $-295 \mathrm{ppm},{ }^{9}$ detected at $198 \mathrm{~K}$ ) were clearly identified in the 1:2 reaction mixture (Eqn. 1). In the spectrum recorded at room temperature, the resonance of $\left[\mathrm{PCl}_{6}\right]^{-}$appeared as a broad one centred at $-190 \mathrm{ppm}$; this fact suggests that, in solution, the anion is probably involved in $\mathrm{Cl}_{5} \mathrm{PCl} \cdots \mathrm{H}-\mathrm{N}$ interaction with the ammonium group belonging to the cation (vide infra).

$$
\begin{aligned}
& L \text {-proline }+\mathrm{nPCl}_{5} \rightarrow\left[\mathrm{NH}_{2}\left(\mathrm{CH}_{2}\right)_{3} \mathrm{CHC}(\mathrm{O}) \mathrm{Cl}\right][\mathrm{X}]+\mathrm{POCl}_{3} \\
& \mathrm{n}=1 \quad \mathrm{X}=\mathrm{Cl}, \mathbf{1} \\
& \mathrm{n}=2 \quad \mathrm{X}=\mathrm{PCl}_{6}, 2
\end{aligned}
$$

The ${ }^{1} \mathrm{H}$ and ${ }^{13} \mathrm{C}$ NMR spectra of the reaction mixtures evidenced the clean formation of the pyrrolidinium-2-carbonylchloride cation (Eqn. 1). The chemical shift values related to 1 are very close to the corresponding ones found for $\mathbf{2}$. The only exception is given by the nitrogen-bound protons $(\mathbf{1}: \delta=$ $10.45,9.42 \mathrm{ppm} ; 2: \delta=9.85,8.73 \mathrm{ppm})$; since the nitrogen formally hosts the positive charge of the cation, this NMR feature is in accord with the different nature of the anion in the two salts (i.e., $\mathrm{Cl}^{-}$in $\mathbf{1}$ and $\left[\mathrm{PCl}_{6}\right]^{-}$in 2). The ${ }^{13} \mathrm{C}$ resonances related to the $\mathrm{CH}_{2}$ moieties resemble those exhibited by $L$-proline in $\mathrm{D}_{2} \mathrm{O},{ }^{10}$ while the resonances due to the carbonyl (1: $171.8 \mathrm{ppm} ; 2: 172.4 \mathrm{ppm} ; L$-proline: $\left.175.8 \mathrm{ppm}\right)$ and $\mathrm{CH}$ groups (1: $67.6 \mathrm{ppm}$; 2: $67.8 \mathrm{ppm}$; $L$-proline: $62.4 \mathrm{ppm}$ ) undergo significant shift with respect to $L$-proline, as consequence of the chlorination. 
In order to shed light into the structural aspects, the structures of $\mathbf{1}$ and $\mathbf{2}$ were optimized by DFT calculations in the presence of an implicit salvation model. The graphical representations are given in Figure 1, while the main bond lengths are compared in Table 1.

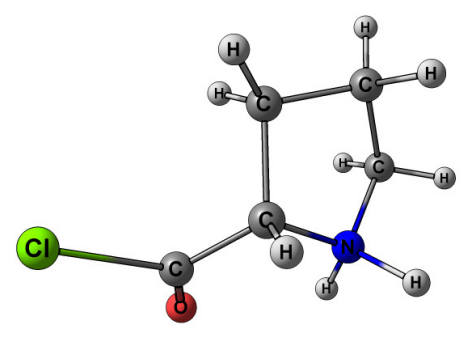

(C)

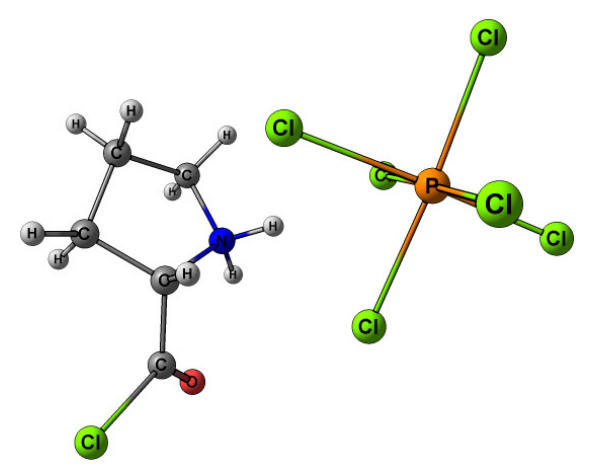

Figure 1. DFT M06/C-PCM calculated structures of $\left[\mathrm{NH}_{2}\left(\mathrm{CH}_{2}\right)_{3} \mathrm{CHC}(\mathrm{O}) \mathrm{Cl}\right] \mathrm{Cl}, \mathbf{1}$, and $\left[\mathrm{NH}_{2}\left(\mathrm{CH}_{2}\right)_{3} \mathrm{CHC}(\mathrm{O}) \mathrm{Cl}\right]\left[\mathrm{PCl}_{6}\right], \mathbf{2}$, with implicit solvation.

Table 1. Selected computed bond distances $(\AA)$ for 1 and 2 (M06/CPCM calculations).

\begin{tabular}{lcc}
\hline & $\mathbf{1}$ & $\mathbf{2}$ \\
\hline $\mathrm{C}=\mathrm{O}$ & 1.177 & 1.191 \\
$\mathrm{C}-\mathrm{Cl}$ & 1.789 & 1.176 \\
$\mathrm{ClC}-\mathrm{C}$ & 1.503 & 1.503 \\
$\mathrm{~N}-\mathrm{CH} \mathrm{H}_{2}$ & 1.497 & 1.518 \\
$\mathrm{~N}-\mathrm{CH}$ & 1.497 & 1.509 \\
$\mathrm{CH}-\mathrm{CH}_{2}$ & 1.550 & 1.531 \\
$\mathrm{CHCH}_{2}-\mathrm{CH}_{2}$ & 1.527 & 1.524 \\
$\mathrm{NCH}_{2}-\mathrm{CH}_{2}$ & 1.511 & 1.517 \\
$\mathrm{P}-\mathrm{Cl}$ & & 2.148 \\
& & 2.149 \\
& & 2.152 \\
& & 2.204 \\
& & 2.206 \\
$\mathrm{CO} \cdots \mathrm{N}$ & & 2.218 \\
$\mathrm{Cl}-\cdots \mathrm{N}$ & 2.771 & 2.225 \\
$\mathrm{PCl} \cdots \mathrm{N}$ (shortest $)$ & 3.001 & \\
& & 3.313
\end{tabular}


According to Table 1, negligible differences are observable with reference to the geometric parameters of the pyrrolidinium-2-carbonylchloride skeleton. In $\mathbf{1}$ and $\mathbf{2}$, respectively, the $\mathrm{Cl}^{-} \cdots \mathrm{N}(3.001 \AA)$ and the shortest $\mathrm{PCl} \cdots \mathrm{N}(3.313 \AA)$ distances are shorter than the sum of the van der Waals radii of $\mathrm{Cl}$ and $\mathrm{N},{ }^{11}$ thus suggesting that $\mathbf{1}$ and $\mathbf{2}$ exist in solution as tight ion pairs. This outcome is coherent with the experimental NMR features (see above). In particular, the electron density surface predicted for 2 (Figure 2) may provide an explanation for the broad, downfield shifted ${ }^{31} \mathrm{P}$ NMR resonance of $\left[\mathrm{PCl}_{6}\right]^{-}$ observed at room temperature (see above). ${ }^{9}$

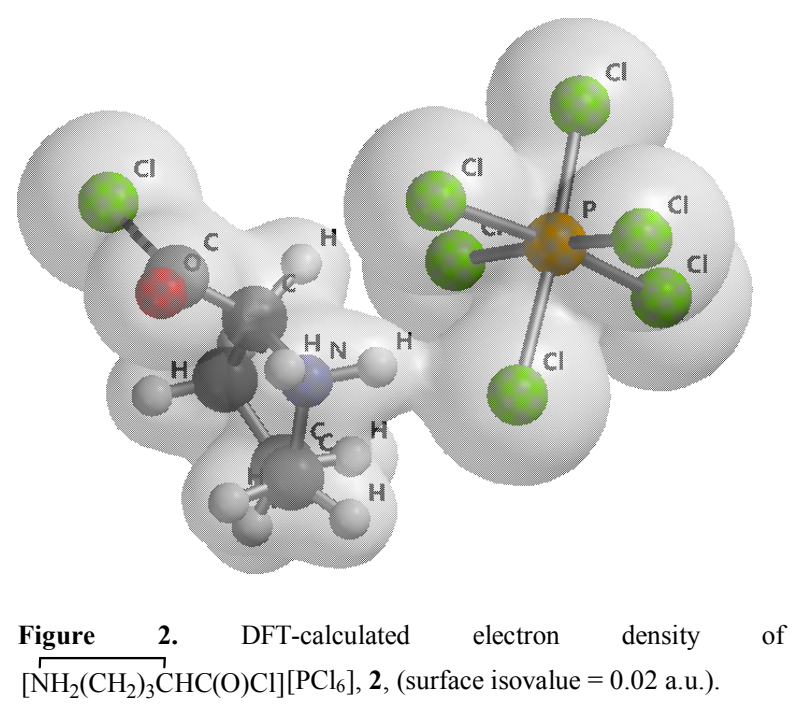

In accordance with the literature reports, $\mathbf{1}$ and $\mathbf{2}$ underwent degradation at $20^{\circ} \mathrm{C}$ with evolution of $\mathrm{HCl}$ when stored under inert atmosphere, both in the solid state and in $\mathrm{CD}_{2} \mathrm{Cl}_{2}$ solution (see Experimental for details). Notwithstanding, the degradation process is significantly faster for $\mathbf{1}$ respect to $\mathbf{2}$, thus indicating some stabilizing effect of the $\left[\mathrm{PCl}_{6}\right]^{-}$anion when compared to $\mathrm{Cl}^{-}$. This is reasonable since the formation of $\mathrm{HCl}$ from 2 requires the breaking of a $\mathrm{P}-\mathrm{Cl}$ bond. NMR experiments carried out on solutions contained in sealed tubes revealed the formation of several decomposition products whose identity could not be ascertained (see Experimental). On the other hand, a different outcome was achieved when $\mathrm{CH}_{2} \mathrm{Cl}_{2}$ solutions of $\mathbf{1}$ or $\mathbf{2}$ were allowed to stir at room temperature for several days with 
periodic flow of nitrogen gas, in order to remove hydrogen chloride from the reaction system. The treatment of the final mixtures with an aqueous solution of $\mathrm{KHCO}_{3}$, followed by chromatography on silica, led to the isolation of $\mathrm{dkp}$ (see Scheme 1). The process appeared much more efficient by using 2 as starting material: in these conditions, dkp was finally recovered in $c a .60 \%$ yield (Scheme 1 ). To the best of our knowledge, this simple procedure has never been described in the literature so far. Dkp was identified by IR ${ }^{12}$ and NMR ${ }^{6 b, 13}$ spectroscopy and GC-MS analysis, moreover optical rotation measurement indicated the retention of configuration respect to the precursor $L$-proline.

The present investigation was extended to a selection of zwitterionic $\alpha$-aminoacids bearing a primary ammonium group (Scheme 1). Thus we carried out the reactions of glycine, $L$-alanine, $L$-phenylalanine and $L$-leucine with $\mathrm{PCl}_{5}$ by using strictly 1:1 molar ratio. The products precipitated from the respective reaction mixtures (in $\mathrm{CCl}_{4}$ or $\mathrm{CH}_{2} \mathrm{Cl}_{2}$ ) and, once isolated, resulted almost insoluble in inert solvents. Their characterization relied on elemental analysis and IR spectroscopy, which suggested the clean formation of $\left[\mathrm{RCH}\left(\mathrm{NH}_{3}\right) \mathrm{C}(\mathrm{O}) \mathrm{Cl}\right][\mathrm{Cl}]\left(\mathrm{R}=\mathrm{H}, \mathbf{3} ; \mathrm{R}=\mathrm{CH}_{3}, \mathbf{4} ; \mathrm{R}=\mathrm{CH}_{2} \mathrm{Ph}, \mathbf{5} ; \mathrm{R}=\mathrm{CH}_{2} \mathrm{CHMe}_{2}, \mathbf{6}\right)$ in very good yields (Eqn. 2).

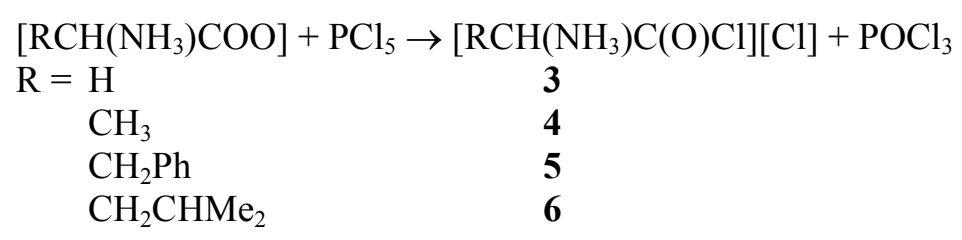

The IR spectra of 3-6 display an intense, diagnostic absorption at $c a .1790 \mathrm{~cm}^{-1}$, closely to what detected for $\mathbf{1}$. The IR spectra of 3-6 did not change after storing the compounds at room temperature for $24-48 \mathrm{~h}$, in the solid state under nitrogen atmosphere. This points suggests that, for the $\alpha$-amino acids reported in Eqn. 2, the employment of one equivalent of $\mathrm{PCl}_{5}$ is sufficient to yield a handleable chlorinated product. We optimized also the structures of 3-6 by DFT calculations. Views of the structures are provided as 
Supporting Information (Figures S1-S4), together with the relevant calculated bonding parameters (Tables S1-S4). The structures of 3-6 resemble that of the homologous salt $\mathbf{1}$, in that tight $\mathrm{Cl}^{-} \cdots \mathrm{N}$ interactions occur between each cation and the chloride anion in the respective cases. Indeed the $\mathrm{Cl}-\mathrm{N}$ distances are all comparable, falling in the range 2.976 to $3.019 \AA$; likewise the thermodynamics for $\mathrm{HCl}$ elimination in dichloromethane do not significantly vary along the series including $\mathbf{1}$ and 3-6 $(\Delta \mathrm{G}=c a .0$ $\mathrm{kcal} \mathrm{mol}^{-1}$ ).

Therefore, in order to give an explanation for the higher stability exhibited by 3-6 in comparison with $\mathbf{1}$, we computed the model reactions of the $\alpha$-amino-acylchloride compounds, derived from $\mathbf{1 , 3 - 6}$ by $\mathrm{HCl}$ release, with acetylchloride $\left[\mathrm{CH}_{3} \mathrm{C}(\mathrm{O}) \mathrm{Cl}\right]$. The calculated $\Delta \mathrm{G}$ values are quite similar, except for the $L$ proline-derived compound showing a more favourable process by about $6 \mathrm{kcal} \mathrm{mol}^{-1}$. According to these outcomes, it may be outlined that $\mathbf{1}$ possesses higher tendency to give self-condensation products with respect to 3-6; this is presumably a consequence of the higher degree of substitution at the $\mathrm{N}$-center, conferring better nucleophilicity in the condensation step.

\section{Conclusions}

Acylchloride derivatives of $\alpha$-aminoacids have been known as reactive species in synthetic chemistry, and they have been generally claimed to be prepared as hydrochloride salts by treatment of the precursors with variable, relative amounts of $\mathrm{PCl}_{5}$. No spectroscopic characterization was reported in the literature. In this paper, we have demonstrated that different anion-based salts may be selectively obtained, by modulating the ratio between the reactants. In the case of $L$-proline, the use of a two-fold excess of $\mathrm{PCl}_{5}$ allows the isolation of the relatively inert $\left[\mathrm{PCl}_{6}\right]^{-}$salt and is strongly preferable in this respect to the 1:1 molar reaction. On the other hand, the 1:1 molar reactions of $\mathrm{PCl}_{5}$ with glycine, $L$ alanine, $L$-phenylalanine and $L$-leucine lead to $[\mathrm{Cl}]^{-}$salts showing satisfying stability at room 
temperature. In agreement with NMR evidences and DFT calculations, the main degradation pathway of the acylchloride products is strictly associated with the occurrence of $\mathrm{N}-\mathrm{H} \cdots \mathrm{Cl}$ cation-anion interactions. However, the self-condensation reaction appears significantly more favoured in the case of the $L$ proline-derived species respect to the other cases, presumably due to the higher nucleophilicity of the amino function. The slow degradation reaction of the pyrrolidinium-2-carbonylchloride $\left[\mathrm{PCl}_{6}\right]^{-}$salt may represent a new, simple and gentle procedure to obtain the $L$-proline-derived 2,5-dieketopiperazine.

\section{Experimental.}

1) General. The reaction vessels were oven dried at $140^{\circ} \mathrm{C}$ prior to use, evacuated $\left(10^{-2} \mathrm{mmHg}\right)$ and then filled with nitrogen. $\mathrm{PCl}_{5}(98+\%), L$-proline (>99\%), glycine (ultrapure), $L$-alanine, $L$ phenylalanine $(>99.5 \%)$ and $L$-leucine $(>99.0 \%)$ were purchased from Apollo Sci. and stored under nitrogen atmosphere as received. Once isolated, the reaction products were conserved in sealed glass tubes under nitrogen. Solvents (Sigma Aldrich) were distilled from $\mathrm{CaH}_{2}$ under argon atmosphere before use. Infrared spectra were recorded at 298 K on a FT IR-Perkin Elmer Spectrometer, equipped with UATR sampling accessory and working in the $650-4000 \mathrm{~cm}^{-1}$ range. NMR spectra were recorded on a Bruker Avance DRX400 instrument equipped with BBFO broadband probe. The chemical shifts for ${ }^{1} \mathrm{H}$ and ${ }^{13} \mathrm{C}$ were referenced to the non-deuterated aliquot of the solvent. The chemical shifts for ${ }^{31} \mathrm{P}$ were

referenced to external $\mathrm{H}_{3} \mathrm{PO}_{4}$. The ${ }^{1} \mathrm{H}$ and ${ }^{13} \mathrm{C}$ NMR spectra were fully assigned via ${ }^{1} \mathrm{H},{ }^{13} \mathrm{C}$ correlation measured through $g s-\mathrm{HSQC}$ and $g s-\mathrm{HMBC}$ experiments. ${ }^{14}$ Optical rotation measurement was performed with a Perkin-Elmer 141 polarimeter ( $\mathrm{Na}$ lamp, $589 \mathrm{~nm}$ ). Carbon, hydrogen and nitrogen analyses were performed on Carlo Erba mod. 1106 instrument. The chloride content was determined by the Mohr method ${ }^{15}$ on solutions prepared by dissolution of the solid in aqueous $\mathrm{KOH}$ at boiling temperature, followed by cooling to room temperature and addition of $\mathrm{HNO}_{3}$ up to neutralization. 


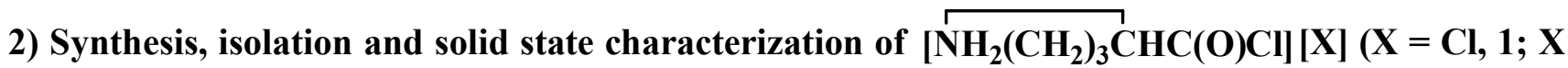

$=\mathbf{P C l}_{6}$, 2). General procedure: A suspension of $\mathrm{PCl}_{5}$ in $\mathrm{CH}_{2} \mathrm{Cl}_{2}(15 \mathrm{~mL})$ in a Schlenk tube was cooled with an ice bath, then $L$-proline was added. The cooled mixture was stirred over 1 hour thus obtaining a colourless solution. Then the volatiles were removed in vacuo affording a colourless residue, which was washed with hexane $(2 \times 20 \mathrm{~mL})$ and dried in vacuo.

2A) $\left[\mathbf{N H}_{2}\left(\mathbf{C H}_{2}\right)_{3} \mathbf{C H C}(\mathbf{O}) \mathbf{C l}\right][\mathbf{C l}]$, 1. From $\mathrm{PCl}_{5}(0.250 \mathrm{~g}, 1.20 \mathrm{mmol})$ and $L$-proline $(0.137 \mathrm{~g}, 1.19$ mmol). Yield $0.162 \mathrm{~g}, 80 \%$. The solid product was maintained at $0-5{ }^{\circ} \mathrm{C}$ before the analyses; it almost completely decomposed after being stored at room temperature under inert atmosphere for one hour. Anal. Calcd. for $\mathrm{C}_{5} \mathrm{H}_{9} \mathrm{Cl}_{2} \mathrm{NO}$ : C, 35.32; H, 5.34; N, 8.24; Cl, 41.70. Found: C, 35.22; H, 5.20; N, 8.37; $\mathrm{Cl}, 41.45$. IR (solid state): $\widetilde{v}=3093 \mathrm{w}-\mathrm{sh}, 2975 \mathrm{w}, 2880 \mathrm{w}, 2666 \mathrm{w}, 1790 \mathrm{vs}(\mathrm{C}=\mathrm{O}), 1540 \mathrm{~m}, 1447 \mathrm{w}-\mathrm{m}$, $1405 \mathrm{~m}, 1358 \mathrm{w}, 1332 \mathrm{~m}, 1302 \mathrm{~m}, 1247 \mathrm{w}, 1167 \mathrm{w}, 1084 \mathrm{~m}, 993 \mathrm{vs}, 952 \mathrm{vs}, 907 \mathrm{~m}, 872 \mathrm{vs}, 818 \mathrm{w}, 779 \mathrm{w}, 739 \mathrm{w}$ $\mathrm{cm}^{-1}$.

2B) $\left[\mathbf{N H}_{2}\left(\mathbf{C H}_{2}\right)_{3} \mathbf{C H C}(\mathbf{O}) \mathbf{C l}\right]\left[\mathbf{P C l}_{\mathbf{6}}\right]$, 2. From $\mathrm{PCl}_{5}(0.320 \mathrm{~g}, 1.54 \mathrm{mmol})$ and $L$-proline $(0.088 \mathrm{~g}, 0.764$ mmol). Yield $0.246 \mathrm{~g}, 85 \%$. The solid product resulted unchanged after $1 \mathrm{~h}$ room temperature under inert atmosphere, but it underwent prevalent decomposition after 24 hours. Anal. Calcd. for $\mathrm{C}_{5} \mathrm{H}_{9} \mathrm{Cl}_{7} \mathrm{NOP}$ : C, 15.88; H, 2.40; N, 3.70; Cl, 65.61. Found: C, 15.59; H, 2.37; N, 3.65; Cl, 65.34. IR (solid state): $\widetilde{v}=$ 3184w (N-H), 2963w, 2879w, 2689w, 1778vs (C=O), 1584w, 1566w-m, 1449w, 1396w-m, 1369w-m, $1291 \mathrm{~m}, 1274 \mathrm{~m}-\mathrm{sh}, 1206 \mathrm{w}, 1070 \mathrm{~m}, 1048 \mathrm{w}, 1002 \mathrm{~s}, 950 \mathrm{~m}, 903 \mathrm{w}, 868 \mathrm{~s}, 849 \mathrm{~m}, 801 \mathrm{w}, 760 \mathrm{w} \mathrm{cm}{ }^{-1}$.

3) Synthesis, isolation and solid state characterization of $\left[\mathrm{RCH}\left(\mathrm{NH}_{3}\right) \mathrm{C}(\mathrm{O}) \mathrm{Cl}\right][\mathrm{Cl}](\mathrm{R}=\mathrm{H}, 3 ; \mathrm{R}=$ $\left.\mathbf{C H}_{3}, 4 ; \mathbf{R}=\mathbf{C H}_{2} \mathbf{P h}, \mathbf{5} ; \mathbf{R}=\mathbf{C H}_{2} \mathbf{C H M e}_{2}, 6\right)$. General procedure: A Schlenk tube, containing a 
suspension of $\mathrm{PCl}_{5}$ in $\mathrm{CH}_{2} \mathrm{Cl}_{2}$ or $\mathrm{CCl}_{4}$, was cooled with an ice bath, then the appropriate $\alpha$-aminoacid was added. The resulting mixture was stirred for 15 minutes, then the ice bath was removed and the stirring was prolonged for further $4 \mathrm{~h}$. The colourless precipitates were isolated, washed with hexane (2 x $20 \mathrm{~mL}$ ) and dried in vacuo.

3A) $\left[\mathbf{C H}_{2}\left(\mathbf{N H}_{3}\right) \mathbf{C}(\mathbf{O}) \mathbf{C l}\right][\mathbf{C l}]$, 3. From $\mathrm{PCl}_{5}(0.250 \mathrm{~g}, 1.20 \mathrm{mmol})$ and glycine $(0.089 \mathrm{~g}, 1.19 \mathrm{mmol})$ in $\mathrm{CCl}_{4}(20 \mathrm{~mL})$. Yield $0.126 \mathrm{~g}, 82 \%$. Anal. Calcd. for $\mathrm{C}_{2} \mathrm{H}_{5} \mathrm{Cl}_{2} \mathrm{NO}: \mathrm{C}, 18.48 ; \mathrm{H}, 3.88 ; \mathrm{N}, 10.77 ; \mathrm{Cl}, 54.55$. Found: C, 18.36; H, 3.95; N, 10.64; Cl, 54.33. IR (solid state): $\widetilde{v}=2987 \mathrm{~m}, 2941 \mathrm{~m}, 2856 \mathrm{~m}, 2595 \mathrm{w}-\mathrm{m}$, $1784 \mathrm{vs}(\mathrm{C}=\mathrm{O}), 1568 \mathrm{~m}, 1494 \mathrm{~m}-\mathrm{s}, 1435 \mathrm{w}, 1418 \mathrm{w}, 1367 \mathrm{~m}, 1296 \mathrm{w}, 1225 \mathrm{~m}, 1113 \mathrm{~m}, 1057 \mathrm{~s}, 963 \mathrm{vs}, 892 \mathrm{~s}$, $860 \mathrm{w}, 745 \mathrm{vs} \mathrm{cm}^{-1}$.

3B) $\left[\mathbf{C H}\left(\mathbf{C H}_{3}\right)\left(\mathbf{N H}_{3}\right) \mathbf{C}(\mathbf{O}) \mathbf{C l}\right][\mathbf{C l}]$, 4. From $\mathrm{PCl}_{5}(0.220 \mathrm{~g}, 1.06 \mathrm{mmol})$ and $L$-alanine $(0.094 \mathrm{~g}, 1.06$ mmol) in $\mathrm{CCl}_{4}(20 \mathrm{~mL})$. Yield $0.131 \mathrm{~g}, 86 \%$. Anal. Calcd. for $\mathrm{C}_{3} \mathrm{H}_{7} \mathrm{Cl}_{2} \mathrm{NO}$ : C, 25.02; $\mathrm{H}, 4.90 ; \mathrm{N}, 9.73$; Cl, 49.24. Found: C, 24.79; H, 4.81; N, 9.82; Cl, 49.03. IR (solid state): $\widetilde{v}=2993 \mathrm{w}-\mathrm{m}, 2940 \mathrm{~m}, 2845 \mathrm{~m}$, 2527w, 1780vs $(\mathrm{C}=\mathrm{O}), 1573 \mathrm{w}-\mathrm{m}, 1526 \mathrm{~m}, 1497 \mathrm{~m}, 1455 \mathrm{w}, 1386 \mathrm{w}, 1348 \mathrm{w}, 1234 \mathrm{w}, 1200 \mathrm{w}-\mathrm{m}, 1131 \mathrm{w}$, $1113 \mathrm{~m}, 1014 \mathrm{w}, 1005 \mathrm{w}, 962 \mathrm{~s}, 882 \mathrm{~m}, 868 \mathrm{~m}, 798 \mathrm{w}, 720 \mathrm{~s} \mathrm{~cm}^{-1}$.

3C) $\left[\mathbf{C H}\left(\mathbf{C H}_{2} \mathbf{P h}\right)\left(\mathbf{N H}_{3}\right) \mathbf{C}(\mathbf{O}) \mathbf{C l}\right][\mathbf{C l}]$, 5. From $\mathrm{PCl}_{5}(0.280 \mathrm{~g}, 1.34 \mathrm{mmol})$ and $L$-phenylalanine $(0.220 \mathrm{~g}$, $1.33 \mathrm{mmol})$ in $\mathrm{CH}_{2} \mathrm{Cl}_{2}(20 \mathrm{~mL})$. Yield $0.234 \mathrm{~g}$, 79\%. Anal. Calcd. for $\mathrm{C}_{9} \mathrm{H}_{11} \mathrm{Cl}_{2} \mathrm{NO}$ : C, 49.11; $\mathrm{H}, 5.04$; N, 6.36; Cl, 32.22. Found: C, 49.02; H, 4.90; N, 6.47; Cl, 31.96. IR (solid state): $\widetilde{v}=2983 \mathrm{w}, 2895 \mathrm{w}-\mathrm{m}$, $2817 \mathrm{~m}, 2699 \mathrm{w}, 2626 \mathrm{w}-\mathrm{m}, 1785 \mathrm{~s}(\mathrm{C}=\mathrm{O}), 1600 \mathrm{w}-\mathrm{m}, 1495 \mathrm{vs}, 1454 \mathrm{w}-\mathrm{m}, 1439 \mathrm{w}-\mathrm{m}, 1347 \mathrm{w}, 1260 \mathrm{w}$, $1225 \mathrm{w}, 1210 \mathrm{w}, 1148 \mathrm{~m}, 1109 \mathrm{~m}, 1084 \mathrm{w}, 1052 \mathrm{w}, 991 \mathrm{vs}, 889 \mathrm{~m}-\mathrm{s}, 880 \mathrm{~m}, 824 \mathrm{~m}, 758 \mathrm{~s}, 734 \mathrm{~s}, 700 \mathrm{vs}, 664 \mathrm{~m}$ $\mathrm{cm}^{-1}$.

3D) $\left[\mathbf{C H}\left(\mathrm{CH}_{2} \mathrm{CHMe}_{2}\right)\left(\mathbf{N H}_{3}\right) \mathbf{C}(\mathbf{O}) \mathbf{C l}\right][\mathrm{Cl}]$, 6. From $\mathrm{PCl}_{5}(0.250 \mathrm{~g}, 1.20 \mathrm{mmol})$ and $L$-leucine $(0.155 \mathrm{~g}$, $1.18 \mathrm{mmol})$ in $\mathrm{CCl}_{4}(20 \mathrm{~mL})$. Yield $0.182 \mathrm{~g}, 83 \%$. Anal. Calcd. for $\mathrm{C}_{6} \mathrm{H}_{13} \mathrm{Cl}_{2} \mathrm{NO}: \mathrm{C}, 38.73 ; \mathrm{H}, 7.04 ; \mathrm{N}$, 7.53; Cl, 38.11. Found: C, 38.44; H, 7.16; N, 7.44; Cl, 38.02. IR (solid state): $\widetilde{v}=3130 \mathrm{w}-\mathrm{br}, 3080 \mathrm{w}$, 
959m, 2870m-s, 2845m-s, 2613w, 1792vs (C=O), 1586m, 1513vs, 1469w, 1436w, 1390w, 1369w, $1341 \mathrm{w}, 1247 \mathrm{w}, 1173 \mathrm{w}, 1106 \mathrm{w}, 1052 \mathrm{w}, 975 \mathrm{vs}, 945 \mathrm{vs}, 831 \mathrm{w}-\mathrm{m}, 752 \mathrm{vs}, 668 \mathrm{w} \mathrm{cm}{ }^{-1}$.

\section{4) NMR studies.}

General procedure: $\mathrm{PCl}_{5}, \mathrm{CD}_{2} \mathrm{Cl}_{2}(0.65 \mathrm{~mL})$ and $L$-proline were introduced into a NMR tube in the order given. The tube was sealed, briefly shaken in order to homogenize the mixture and maintained at $c a .5^{\circ} \mathrm{C}$. After 30 minutes, the content of the tube appeared as a colourless solution, which was promptly analyzed. The solution turned red after 24 hours at room temperature; subsequent NMR spectra showed the presence of a complicated mixture of products.

4A) From $\mathrm{PCl}_{5}(0.200 \mathrm{~g}, 0.960 \mathrm{mmol})$ and $L$-proline $(0.111 \mathrm{~g}, 0.964 \mathrm{mmol}) .{ }^{1} \mathrm{H} \mathrm{NMR}\left(\mathrm{CD}_{2} \mathrm{Cl}_{2}, 278 \mathrm{~K}\right)$ : $\delta=10.45,9.42\left(\mathrm{br}, 2 \mathrm{H}, \mathrm{NH}_{2}\right) ; 4.99(\mathrm{br}, 1 \mathrm{H}, \mathrm{CH}) ; 3.58\left(\mathrm{br}, 2 \mathrm{H}, \mathrm{NCH}_{2}\right) ; 2.61,2.39\left(\mathrm{~m}, 2 \mathrm{H}, \mathrm{CH}_{2}\right) ; 2.17$, $2.11 \mathrm{ppm}\left(\mathrm{m}, 2 \mathrm{H}, \mathrm{CH}_{2}\right) .{ }^{13} \mathrm{C}\left\{{ }^{1} \mathrm{H}\right\} \operatorname{NMR}\left(\mathrm{CD}_{2} \mathrm{Cl}_{2}, 278 \mathrm{~K}\right): \delta=171.8(\mathrm{C}=\mathrm{O}) ; 67.6(\mathrm{CH}) ; 46.5\left(\mathrm{NCH}_{2}\right)$; 29.1, 23.1 ppm $\left(\mathrm{CH}_{2}\right) .{ }^{31} \mathrm{P}$ NMR $\left(\mathrm{CD}_{2} \mathrm{Cl}_{2}, 278 \mathrm{~K}\right): \delta=4.6 \mathrm{ppm}\left(\mathrm{s}, \mathrm{POCl}_{3}\right)$.

4B) From $\mathrm{PCl}_{5}(0.250 \mathrm{~g}, 1.20 \mathrm{mmol})$ and $L$-proline $(0.069 \mathrm{~g}, 0.600 \mathrm{mmol}) .{ }^{1} \mathrm{H} \mathrm{NMR}\left(\mathrm{CD}_{2} \mathrm{Cl}_{2}, 298 \mathrm{~K}\right): \delta$ $=9.85,8.73\left(\right.$ br, $\left.2 \mathrm{H}, \mathrm{NH}_{2}\right) ; 4.95(\mathrm{br}, 1 \mathrm{H}, \mathrm{CH}) ; 3.58\left(\mathrm{br}, 2 \mathrm{H}, \mathrm{NCH}_{2}\right) ; 2.64,2.37\left(\mathrm{~m}, 2 \mathrm{H}, \mathrm{CH}_{2}\right) ; 2.12$ ppm (br, $\left.2 \mathrm{H}, \mathrm{CH}_{2}\right) .{ }^{13} \mathrm{C}\left\{{ }^{1} \mathrm{H}\right\} \mathrm{NMR}\left(\mathrm{CD}_{2} \mathrm{Cl}_{2}, 298 \mathrm{~K}\right): \delta=172.4(\mathrm{C}=\mathrm{O}) ; 67.8(\mathrm{CH}) ; 47.4\left(\mathrm{NCH}_{2}\right) ; 29.3$, $23.4 \mathrm{ppm}\left(\mathrm{CH}_{2}\right) .{ }^{31} \mathrm{P}$ NMR $\left(\mathrm{CD}_{2} \mathrm{Cl}_{2}, 298 \mathrm{~K}\right): \delta=4.7\left(\mathrm{~s}, \mathrm{POCl}_{3}\right) ;-190 \mathrm{ppm}\left(\mathrm{br}, \Delta v^{1 / 2}=1.4 \cdot 10^{3} \mathrm{~Hz}\right) .{ }^{31} \mathrm{P}$ $\operatorname{NMR}\left(\mathrm{CD}_{2} \mathrm{Cl}_{2}, 198 \mathrm{~K}\right): \delta=8.7\left(\mathrm{~s}, \mathrm{POCl}_{3}\right) ;-294.6 \mathrm{ppm}\left(\mathrm{br}, \Delta v^{1 / 2}=15 \mathrm{~Hz}, \mathrm{PCl}_{6}{ }^{-}\right)$.

\section{5) Synthesis and isolation of $(S, S)$-octahydrodipyrrolo[1,2-a:1',2'-d]pyrazine-5,10-dione (dkp). A} suspension of $\mathrm{PCl}_{5}(1.10 \mathrm{~g}, 5.28 \mathrm{mmol})$ in $\mathrm{CH}_{2} \mathrm{Cl}_{2}(20 \mathrm{~mL})$ was treated with $L$-proline $(0.300 \mathrm{~g}, 2.61$ mmol). The mixture was stirred at room temperature for 11 days. During this period of time, the system was purged with nitrogen in order to remove the released gas $(\mathrm{HCl})$. Bubbling the latter into an aqueous 
solution of $\mathrm{AgNO}_{3}$ determined the precipitation of a white solid $(\mathrm{AgCl})$. Then a $0.2 \mathrm{M}$ aqueous solution of $\mathrm{KHCO}_{3}(25 \mathrm{~mL})$ was added. The organic phase was separated and charged on a silica pad. The use of a mixture $(1: 1 \mathrm{v} / \mathrm{v})$ of diethyl ether and acetone as eluent allowed to isolate a fraction corresponding to dkp. The product was afforded as a light-yellow solid upon removal of the volatile materials in vacuo. Yield 0.154 g, 61\%. Anal. Calcd. for $\mathrm{C}_{10} \mathrm{H}_{14} \mathrm{~N}_{2} \mathrm{O}_{2}$ : C, 61.84; H, 7.27; N, 14.42. Found: C, 61.67; H, 7.25; N, 14.21. IR (solid state): $\widetilde{v}=2973 \mathrm{w}, 2956 \mathrm{w}, 2883 \mathrm{w}, 1654 \mathrm{vs}(\mathrm{C}=\mathrm{O}),{ }^{12} 1512 \mathrm{w}, 1428 \mathrm{~s}, 1336 \mathrm{~m}$, $1292 \mathrm{w}-\mathrm{m}, 1279 \mathrm{~m}, 1259 \mathrm{~m}, 1235 \mathrm{w}-\mathrm{m}, 1202 \mathrm{w}, 1160 \mathrm{~m}, 1069 \mathrm{w}, 1020 \mathrm{w}, 1001 \mathrm{w}, 920 \mathrm{w}-\mathrm{m}, 802 \mathrm{~m}, 749 \mathrm{~s}$, $664 \mathrm{~m} \mathrm{~cm}^{-1} .{ }^{1} \mathrm{H}$ NMR $\left(\mathrm{CDCl}_{3}\right): \delta=4.18(\mathrm{~m}, 1 \mathrm{H}, \mathrm{CH}) ; 3.52\left(\mathrm{~m}, 2 \mathrm{H}, \mathrm{NCH}_{2}\right) ; 2.29,2.17\left(\mathrm{~m}, 2 \mathrm{H}, \mathrm{CH}_{2}\right)$; 2.01, $1.91 \mathrm{ppm}\left(\mathrm{m}, 2 \mathrm{H}, \mathrm{CH}_{2}\right) .{ }^{13} \mathrm{C}\left\{{ }^{1} \mathrm{H}\right\} \mathrm{NMR}\left(\mathrm{CDCl}_{3}\right): \delta=166.4(\mathrm{C}=\mathrm{O}) ; 60.4(\mathrm{CH}) ; 45.2\left(\mathrm{NCH}_{2}\right) ; 27.7$, $23.3 \mathrm{ppm}\left(\mathrm{CH}_{2}\right)$. GC-MS: $195\left([\mathrm{M}+1]^{+}\right) \cdot[\alpha]_{\mathrm{D}}{ }^{25}=-67\left(c 1, \mathrm{CH}_{3} \mathrm{OH}\right) .{ }^{12}$

6) Computational studies. The computational geometry optimization of the complexes was carried out without symmetry constrains, using the hybrid DFT EDF2 functional ${ }^{16}$ in combination with the 6$31 \mathrm{G}(\mathrm{d}, \mathrm{p})$ basis set. ${ }^{17}$ Further geometry optimization was performed using the hyper-GGA functional M06 ${ }^{18}$ in combination with the C-PCM implicit solvation model $(\varepsilon=9.08){ }^{19}$ and the $6-311 \mathrm{G}(\mathrm{d}, \mathrm{p})$ basis set. ${ }^{20}$ In all of the cases the stationary points were characterized by IR simulations. ${ }^{21}$ DFT-simulated IR data, obtained with harmonic approximation, assisted the interpretation of experimental IR spectra.

Supporting information. The structures of 3-6 are provided as Supporting Information (Figures S1-S4), together with relevant calculated bonding parameters (Tables S1-S4). The Cartesian coordinates of all the optimized structures are collected in a separated .xyz file.

\section{References and Notes}


1 See for instance: (a) Á. L. Fuentes de Arriba, L. Simón, C. Raposo, V. Alcázar, J. R. Morán, Tetrahedron 65 (2009) 4841-4845. (b) F. M. Muñiz, L. Simón, V. Alcázar, C. Raposo, C.; Á. L. Fuentes de Arriba, J. R. Morán, Eur. J. Org. Chem. (2009) 5350-5354. (c) J. L. Morell, P. Fleckenstein, E. J. Gross, Org. Chem. 42 (1977) 355-356. (d) C. Abate, R. Kolanos, M. Dukat, V. Setola, B. L. Roth, R. A. Glennon, Bioorg. \& Med. Chem. Lett. 15 (2005) 3510-3513. (e) A. Nagai, T. Miyagawa, H. Kudo, T. Endo, Macromolecules 36 (2003) 9335-9339. (f) A. Ookawa, K. J. Soai, Chem. Soc., Perkin Trans. 1 (1987) 1465-1471. (g) S. M. Jones, J. E. Urch, M. Kaiser, R. Brun, J. L. Harwood, C. Berry, I. H. Gilbert, J. Med. Chem. 48 (2005) 5932-5941. (h) P. G. Andersson, D. Guijarro, D. J. Tanner, Org. Chem. 62 (1997) 7364-7375. i) S. E. Mallakpour, A.-R. Hajipour, A.-R. Mahdavian, S. Khoee, J. Pol. Sci., Part A: Pol. Chem. 37 (1999) 1211-1219.

2 (a) S. Levine, J. Am. Chem. Soc. 76 (1954) 1382. (b) Y. Liwschitz, A. Zilkha, H. Borensztain, M. Frankel, J. Org. Chem. 21 (1956) 1531-1532.

3 (a) M. Bortoluzzi, E. Ferretti, F. Marchetti, G. Pampaloni, S. Zacchini, Chem. Commun. 50 (2014) 4472-4474. (b) F. Marchetti, G. Pampaloni, C. Pinzino, Chem. Eur. J. 19 (2013) 13962-13969. (c) F. Marchetti, G. Pampaloni, Chem. Commun. 48 (2012) 635-653.

4 (a) M. P. de Carvalho, W.-R. Abraham, Curr. Med. Chem. 19 (2012) 3564-3577. (b) C. Cornacchia, I. Cacciatore, L. Baldassarre, A. Mollica, F. Felician, F. Pinnen, Mini-Rev. Med. Chem. 12 (2012) 2-12.

5 (a) A. D. Borthwick, Chem. Rev. 112 (2012) 3641-3716. (b) A. S. M. Ressurreição, R. Delatouche, C. Gennari, U. Piarulli, Eur. J. Org. Chem. (2011) 217-228.

6 (a) H. Thajudeen, K. Park, S.-S. Moon, I. S. Hong, Tetrahedron Lett. 51 (2010) 1303-1305. (b) M. Jainta, M. Nieger, S. Bräse, Eur. J. Org. Chem. (2008) 5418-5424. (c) M. Movassaghi, M. A. Schmidt, J. A. Ashenhurst, Angew. Chem. Int. Ed. 47 (2008) 1485-1487. 
7 (a) H. Chen, X. Xu, L. Liu, G. Tang, Y. Zhaoa, RSC Adv. 3 (2013) 16247-16250. (b) H. Dehghani, M. Shaterian, Inorg. Chim. Acta 362 (2009) 5151-5154.

8 C. E. Check, K. C. Lobring, P. R. Keating, T. M. Gilbert, L. S. Sunderlin, J. Phys. Chem. A 107 (2003) 8961-8967.

9 (a) A. S. Muir, Polyhedron 10 (1991) 2217-2219. (b) L. I. Larina, V. G. Rozinov, M. Dmitrichenko, L. A. Eskova, Magn. Res. Chem. 47 (2009) 149-157.

10 Spectral Database for Organic Compounds. http://riodb01.ibase.aist.go.jp/sdbs/cgibin/direct_frame_top.cgi.

11 S. S. Batsanov, Inorg. Mat. 37 (2001) 871-885.

12 X. Hu, Z. Shan, W. Li, J. Fluorine Chem. 131 (2010) 505-509.

13 N. A. J. C. Furtado, M. T. Pupo, I. Carvalho, V. L. Campo, M. C. T. Duarte, J. K. Bastos, J. Braz. Chem. Soc. 16 (2005) 1448-1453.

14 W. Willker, D. Leibfritz, R. Kerssebaum, W. Bermel, Magn. Reson. Chem., 31 (1993) 287-292.

15 D. A. Skoog, D. M. West, F. Holler, J. Fundamentals of Analytical Chemistry, 7th Edition, Thomson Learning, Inc, USA (1996).

16 C. Y. Lin, M. W. George, P. M. W. Gill, Aust. J. Chem. 57 (2004) 365-370.

17 W. J. Henre, R. Ditchfield, J. A. Pople, J. Chem. Phys. 56 (1972) 2257-2261.

18 Y. Zhao, D. G. Truhlar, Theor. Chem. Acc. 120 (2008) 215-241.

19 (a) V. Barone, M. Cossi, J. Phys. Chem. A 102 (1998) 1995-2001. (b) M. Cossi, N. Rega, G. Scalmani, V. Barone, J. Comput. Chem. 24 (2003) 669-681.

20 A. D. McLean, G. S. Chandler, J. Chem. Phys. 72 (1980) 5639-5648.

21 C. J. Cramer, Essentials of Computational Chemistry, $2^{\text {nd }}$ Ed., Wiley, Chichester (2004). 
